\title{
COMPARISON OF SURGICAL INTERVENTIONS FOR DEGENERATIVE DEFORMITIES AND INSTABILITY OF THE SPINE AMONG ELDERLY PATIENTS
}

\author{
A COMPARAÇÃO DE INTERVENÇÕES CIRÚRGICAS PARA PACIENTES IDOSOS COM \\ DEFORMAÇÔES DEGENERATIVAS E INSTABILIDADE DA COLUNA VERTEBRAL
}

\author{
COMPARACIÓN DE INTERVENCIONES QUIRÚRGICAS PARA PACIENTES ANCIANOS CON \\ DEFORMACIONES DEGENERATIVAS E INESTABILIDAD DE LA COLUMNA VERTEBRAL
}

Ditril Mikhaylov ${ }^{1}$, Anton Denisov', Dmitril Ptashnikov' ${ }^{1}$ Sergel Masevnin ${ }^{1}$, Nikita Zaborovgkil ${ }^{1}$

1. Spine Surgery and Oncology Department R. R.Vreden Russian Research Institute ofTraumatology and Orthopedics. Saint Petersburg, Russia.

\begin{abstract}
Objective: To evaluate the surgical results among elderly patients with degenerative deformities and instability of the spine. Methods: A retrospective study of 437 patients (337 women, 100 men) with a mean age 60. The mean follow-up time was five years. The inclusion criteria were diseases and complications following spinal trauma associated with deformities, degenerative processes, acute pain syndrome, and spinal stenosis with neurological deficit. Four study groups (A, B, C and D) were created and defined by type of surgical intervention. Group A patients (the reference group) - decompression of neural structures on both sides without fixation. Group B - decompression and transpedicular fixation performed without correction of the deformity. Group C - patients operated up to the lower-thoracic region with transpedicular screws, correction of the deformity and decompression of spinal stenosis. Group D - transpedicular fixation up to higher-thoracic region; correction of the deformity and decompression of neurological structures. The mean follow-up time was five years. Results: Group D patients achieved the best outcome. The results observed were good in $57.2 \%$ of cases (60 patients); satisfactory in $40 \%$ of cases (42 patients); and unsatisfactory in $2.8 \%$ of cases (three patients). The worst findings were observed in Group A: satisfactory in $13.4 \%$ of cases (15 patients); and, unsatisfactory in $86.6 \%$ of cases (97 patients). No good results were observed in this group. Conclusion: The results suggest that performing full deformity correction with transpedicular fixation up to the higher-thoracic region gives the best outcomes for elderly patients, and helps to prevent long-term complications. Evidence level III; Retrospective Comparative Study.
\end{abstract}

Keywords: Scoliosis; Osteotomy; Patient health questionnaire.

\section{RESUMO}

Objetivo: Avaliar os resultados da operação em idosos com deformações degenerativas e instabilidade da coluna vertebral. Método: Estudo retrospectivo de 437 pacientes (337 mulheres, 100 homens) com idade média de 60 anos. A duração média da obsenvação foi de cinco anos. Os critérios de inclusão foram doenças e complicações após uma deformidade, processos degenerativos, síndrome da dor aguda e estenose espinhal com déficit neurológico. Quatro grupos de estudo ( $A, B, C$ e D) foram criados por tipo de intervenção cirúrgica. Grupo A (grupo de referência): descompressão das estruturas neuronais de ambos os lados sem fixação. Grupo B: descompressão e fixação transpedicular realizadas sem correção. Os pacientes do grupo C foram submetidos à cirurgia para região torácica inferior com parafusos transpediculares, correção e descompressão. Grupo D com fixação transpedicular na região torácica alta; correção total; descompressão de estruturas neurológicas. A duração média da observação foi de cinco anos. Resultados: no grupo D, melhores resultados foram observados. Bons resultados em $57,2 \%$ dos casos (60 pacientes); satisfatório em 40\% dos casos (42 pacientes); e insatisfatório em 2,8\% (3 pacientes). Os piores resultados foram obtidos no Grupo A. Resultados satisfatórios em 13,4\% dos casos (15 pacientes); e insatisfatório em 86,6\% dos casos (97 pacientes). Conclusão: Os resultados sugerem que a realização de uma correção completa da deformidade com fixação transpedicular na região torácica alta leva a melhores desfechos para pacientes idosos e ajuda a evitar complicações em longo prazo. Nível de evidência III; Estudo Retrospecitvo Comparativo.

Descritores: Escoliosis; Osteotomía; Questionário de saúde do paciente.

\section{RESUMEN}

Objetivo: Evaluar los resultados quirúrgicos en pacientes ancianos con deformaciones degenerativas e inestabilidad de la columna vertebral. Métodos: Estudio retrospectivo de 437 pacientes (337 mujeres, 100 hombres) con edad promedio de 60 años. La duración media de la observación fue de 5 años. Los criterios para la inclusión fueron enfermedades y complicaciones posteriores a traumatismo espinal asociado con deformidades, procesos degenerativos, síndrome de dolor agudo y estenosis espinal con déficit neurológico. Se crearon cuatro grupos de estudio ( $A, B, C$ y D) por tipo de intervención quirúrgica. Grupo A (el grupo de referencia): descompresión de las estructuras neuronales en ambos lados sin fijación. Grupo B: descompresión y fijación transpedicular realizadas sin corrección de la deformidad. Los pacientes del grupo C habían sido operados hasta la región torácica inferior con tornillos transpediculares, corrección de la deformidad y descompresión de la estenosis espinal. Grupo D con fijación transpedicular hasta la región torácica superior, corrección de la deformidad y descompresión de estructuras neurológicas. La duración media de la observación fue cinco años. Resultados: En grupo D se observaron mejores resultados. Los resultados obsenados fueron buenos en $57,2 \%$ de los casos (60 pacientes); satisfactorios en $40 \%$ de los casos (42 pacientes) e insatisfactorios en 2,8\% (tres pacientes). Los peores resultados se obtuvieron en el Grupo A. Resultados satisfactorios en 13,4\% de los casos (15 pacientes) e insatisfactorios en $86,6 \%$ de los casos (97 pacientes). No se observaron buenos resultados en este grupo. Conclusión: Los resultados sugieren que realizar una corrección de deformidad completa con fijación transpedicular hasta zona torácica superior lleva a mejores resultados para pacientes de edad avanzada y ayuda a evitar complicaciones a largo plazo. Nivel de evidencia III; Estudio Retrospectivo Comparativo.

Descriptores: Escoliosis; Osteotomía; Cuestionário de salud del paciente. 


\section{INTRODUCTION}

Treating degenerative spinal deformities accompanied by segment instability in elderly patients is problematic, and improved approaches are needed. The deformity is prevalent, affecting up to $60 \%$ of senior aged people. In the USA, around 3.3 billion dollars per annum is spent on treating spinal deformities in patients aged 60 years or older. ${ }^{1-3}$

Recently, surgical treatment for severe lesions has become more common. Degenerative spinal deformities are present in segment instability and secondary spinal stenosis. ${ }^{1,3-6}$ New surgical techniques and modern anesthetic procedures are enabling patients of any age to be operated on, even if they present severe somatic pathology.

A crucial link in further medical tactics for senior age patients with spinal column deformities is the pathological changes that occur in the bone-ligament formations and spinal cord. Resolving skeletal and neurological problems simultaneously requires a combined neuro-orthopedic approach; hence, surgical treatment should be combined with stabilizing and decompressing interferences. ${ }^{4,9}$

Where old age is combined with severe somatic pathology, the extensiveness of surgical intervention should still preserve opportunities for self-reliance and social activity. 5,6,8,10,11

Though understanding of treatment volume is quite clearly defined in general terms, this not the case for elderly patients. ${ }^{5-7,12}$

It is clear from the current literature that further research is needed on the subject of treating elderly patients with deformities, spinal stenosis, and segment instability. It is necessary to specify the indications, extent, and priority of operational treatment for this patient category, and to improve the forms of surgical treatment.

\section{Aim of the study}

To compare surgical treatment results among elderly patients with degenerative deformities and instability of the spine.

\section{METHODS}

Ethical approval. The study was approved by the research ethics committee.

Patient consent. All patients gave their informed consent prior to being included into the study.

Retrospective study of 437 patients (337 women, 100 men) with a mean age 60, operated at the Russian Orthopaedic Institute of Traumatology and Orthopaedics - Vreden R.R. The follow-up period was 5 years (operated from 2002 to 2012).

\section{Inclusion criteria}

1. 60 years or older

2. presence of spinal deformity with Cobb angle of more than $30^{\circ}$

3. multiple spinal stenosis

4. Neurological deficit (Paresthesia of the lower limbs 3.5 points) and intensive acute pain syndrome (VAS score 7 and above)

5. Prior decompression of neural structures, with or without correction of the deformity.

The mean age of the patients was 68 years (range from 60 to 88 years). The majority of the patients (337 or $77 \%$ ) were women, and $100(23 \%)$ were male.

Etiologically, all the patients were separated into 3 groups: (1) 137 had vertebral column instability and neurological deficit due to degenerative process after idiopathic and kyphotic deformity; (2) 170 patients had degenerative scoliosis, and (3) 130 had posttraumatic deformities (more than 6 months after the incidence) plus the presence of degeneration.

Four groups were created for analysis, based on the type of surgical intervention performed.

Group A comprised patients with prior decompression of neural structures on both sides without fixation (reference group).

Group B comprised patients who underwent decompression and transpedicular fixation performed for spinal segments without correction of the deformity.

Patients of Group C underwent surgery up to the lower-thoracic region with transpedicular screws, correction of the deformity, and decompression of spinal stenosis.
Group D patients underwent transpedicular fixation up to higherthoracic region, correction of the deformity, and decompression of neurological structures.

The duration of observation was 5 years

All patients had passed a total complex preoperative test, including radiological and clinical methods. Additionally, information was obtained on mineral bone density by the DEXA method.

Spinal deformity criteria were evaluated using the Schwab-SRS Adult Spinal Deformity classification. ${ }^{10}$ A summary of the types of deformity is shown in Table 1.

Nearest, mid-term, and long-term treatment results were evaluated using the VAS scale, Oswestry Disability Index, and SRS-24. The degree of neurological breaches was determined by neurological examination. The influence of intermittent lameness was reflected in quality-of-life questionnaires. A summary of the results of the four groups is shown in Table 2.

\section{Statistical data processing}

Dispersion analysis - ANOVA (Tukey HSD test) was performed using the software program Statistica 10. Confidence intervals were calculated by the improved Wald test, and normality of distribution was verified by the Shapiro-Wilk test.

A detailed study of the patients' data revealed that all the results were comparable (in terms of level of the pain, degree and significance of the deformity, and quality of life), which enabled us to conduct a comparative analysis and to consider all distinctions in the postoperative period related to the surgical treatment.

Table 1. Summary of deformity types using the Schwab-SRS Adult Spinal Deformity classification.

\begin{tabular}{|c|c|c|c|c|}
\hline \multirow[t]{2}{*}{$\begin{array}{l}\text { Type of } \\
\text { deformity }\end{array}$} & \multicolumn{2}{|c|}{ Modifier } & \multicolumn{2}{|c|}{$\begin{array}{l}\text { Number of patients (\% from the } \\
\text { sample) (boundaries of confidence } \\
\text { interval Wald) }\end{array}$} \\
\hline & PI-LL & PT & Global Balance & \\
\hline \multirow{3}{*}{ L } & $A\left(<10^{\circ}\right)$ & $L\left(<20^{\circ}\right)$ & $\mathrm{N}(\mathrm{SVA}<4 \mathrm{~cm})$ & $\begin{array}{c}35(8 \%) \\
(0.0579-0.1096) \\
\end{array}$ \\
\hline & B $\left(10^{\circ}-20^{\circ}\right)$ & $M\left(20-30^{\circ}\right)$ & P(SVA4-9.5 cm) & $\begin{array}{c}56(12.7 \%) \\
(0.0999-0.1629) \\
\end{array}$ \\
\hline & $C\left(>20^{\circ}\right)$ & $\mathrm{H}\left(>30^{\circ}\right)$ & $P V(S V A>9.5 \mathrm{~cm})$ & $\begin{array}{c}61(14 \%) \\
(0.1101-0.1754) \\
\end{array}$ \\
\hline \multirow{3}{*}{ D } & $A\left(<10^{\circ}\right)$ & $L\left(<20^{\circ}\right)$ & $\mathrm{N}(\mathrm{SVA}<4 \mathrm{~cm})$ & $\begin{array}{c}72(16.5 \%) \\
(0.1328-0,2026)\end{array}$ \\
\hline & $B\left(10^{\circ}-20^{\circ}\right)$ & $\mathrm{M}\left(20-30^{\circ}\right)$ & P(SVA4-9.5 cm) & $\begin{array}{c}86(19.7 \%) \\
(0.1621-0,2367)\end{array}$ \\
\hline & $C\left(>20^{\circ}\right)$ & $\mathrm{H}\left(>30^{\circ}\right)$ & $P V(S V A>9.5 \mathrm{~cm})$ & $\begin{array}{c}61(14 \%) \\
(0.1101-0.1754)\end{array}$ \\
\hline \multirow{2}{*}{ S } & \multirow{2}{*}{ B $\left(10^{\circ}-20^{\circ}\right)$} & $\mathrm{M}\left(20-30^{\circ}\right)$ & P(SVA4-9.5 cm) & $\begin{array}{c}38(38(8.7 \%) \\
(0.0638-0.1173) \\
\end{array}$ \\
\hline & & $\mathrm{H}\left(>30^{\circ}\right)$ & $P V(S V A>9.5 \mathrm{~cm})$ & $\begin{array}{c}28(28(6.4 \%) \\
(0.0393-0.1019)\end{array}$ \\
\hline
\end{tabular}

Table 2. Summary table of patient parameters.

\begin{tabular}{|c|c|c|c|c|c|}
\hline \multirow{2}{*}{$\begin{array}{l}\text { Parameters } \\
\text { before } \\
\text { surgery } \\
\end{array}$} & \multicolumn{4}{|c|}{ Groups } & \multirow[b]{2}{*}{ p } \\
\hline & A & B & C & D & \\
\hline age & 69 (62-78) & $70(60-80)$ & $72(63-81)$ & $72(62-82)$ & 0.17 \\
\hline men & 23 & 27 & 24 & 26 & 0.21 \\
\hline women & 89 & & & & 0.35 \\
\hline $\begin{array}{l}\text { VAS mean } \\
\text { value (SD) }\end{array}$ & $8( \pm 2.2)$ & $8( \pm 2.4)$ & $8( \pm 1.9)$ & $8( \pm 2.3)$ & 0.24 \\
\hline $\begin{array}{c}\text { ODI mean } \\
\text { value \% (SD) }\end{array}$ & $77.4( \pm 4.1)$ & $78.5( \pm 3.8)$ & $78.1( \pm 4.2)$ & $77.3( \pm 3.2)$ & 0.19 \\
\hline $\begin{array}{c}\text { SRS-24 mean } \\
\text { value (SD) }\end{array}$ & $1.9( \pm 0.6)$ & $1.9( \pm 0.5)$ & $1.9( \pm 0.4)$ & $1.9( \pm 0.8)$ & 0.38 \\
\hline paresis & - & - & - & - & \\
\hline PI-LL (SD) & $22.4^{\circ}( \pm 3.7)$ & $23.3^{\circ}( \pm 3.6)$ & $23^{\circ}( \pm 4.2)$ & $22.7^{\circ}( \pm 3.9)$ & 0.27 \\
\hline $\mathrm{PT}(\mathrm{SD})$ & $34.3^{\circ}( \pm 4.3)$ & $33.5^{\circ}( \pm 2.9)$ & $35.5^{\circ}( \pm 3.1)$ & $34.2^{\circ}( \pm 4.2)$ & 0.176 \\
\hline LL (SD) & $12.3^{\circ}( \pm 2.1)$ & $13.1^{\circ}( \pm 1.9)$ & $12.7^{\circ}( \pm 2.8)$ & $12.9^{\circ}( \pm 2.5)$ & 0.13 \\
\hline TK (SD) & $44.7^{\circ}( \pm 4.7)$ & $45.2^{\circ}( \pm 5.1)$ & $44.3^{\circ}( \pm 5.3)$ & $45.1^{\circ}( \pm 4.4)$ & 0.22 \\
\hline SVA (SD) & $7.3 \mathrm{~cm}( \pm 2.2)$ & $7.9 \mathrm{~cm}( \pm 2.4)$ & $8.1 \mathrm{~cm}( \pm 1.9)$ & $7.5 \mathrm{~cm}( \pm 1.7)$ & 0.178 \\
\hline CSA (SD) & $4.5 \mathrm{~cm}( \pm 1.3)$ & $3.9 \mathrm{~cm}( \pm 1.7)$ & $4.4 \mathrm{~cm}( \pm 1.4)$ & $4.2 \mathrm{~cm}( \pm 1.5)$ & 0.183 \\
\hline Cobb (SD) & $38.3^{\circ}( \pm 4.8)$ & $38.1^{\circ}( \pm 5.2)$ & $37.7^{\circ}( \pm 4.5)$ & $38.4^{\circ}( \pm 5.3)$ & 0.16 \\
\hline
\end{tabular}




\section{Surgical interventions}

The patients of Group A underwent decompression of the spinal canal by foraminotomy via the tubular approach (one-two segments) or the central posterior approach (more than two segments).

The patients of Group B underwent fixation by transpedicular screws to stabilize the vertebral column without correction of the deformity, and neural decompression of the involved segments. (Figure 1)

The patients of Group C underwent fixation up to lower-thoracic region with correction and decompression. Monoaxial and uniplanar screws were added to correct the vertebral rotation. (Figure 2)

The patients of Group D underwent fixation up to higher-thoracic region with correction and decompression of spinal stenosis.

\section{RESULTS}

X-ray control was carried out at 3, 6, 12, and 18 months during the first 18 months of postoperative follow-up, and once in a year after the initial follow-up period.

The results were evaluated intra-group and inter-group, and compared with the primary data. The clinical control was carried out at 3, 612 , and 18 months in the first year, and at two and five years after surgery.

The results showed different levels of pain in each of the patient groups. (Figure 3)

The early postoperative result in Group A was an even decrease in the level of pain, which can be explained by the type of surgical intervention performed. Similar results were found in Group B and
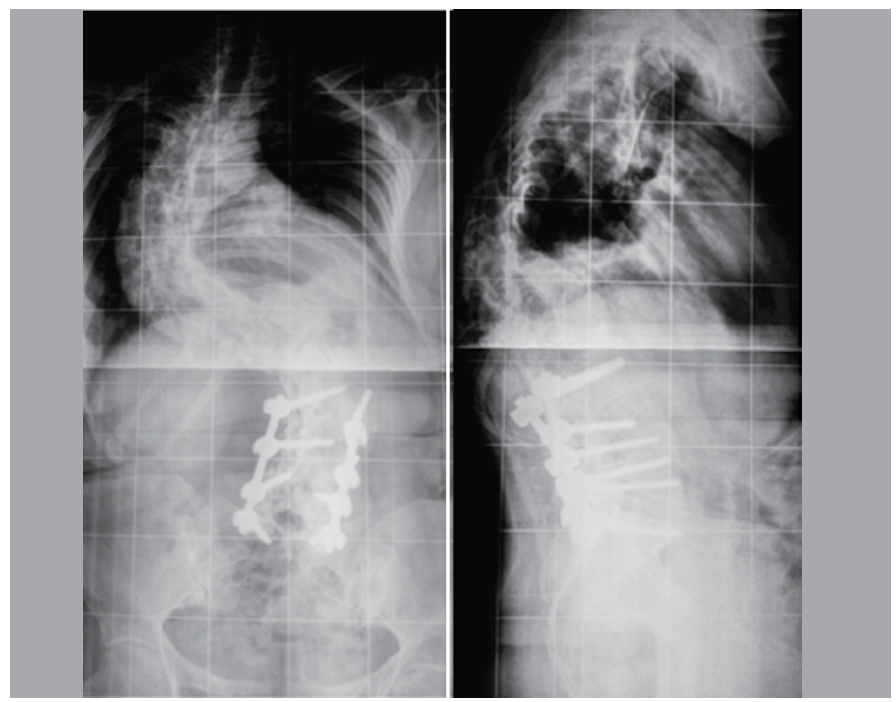

Figure 1. X-ray of patient 63 years, with the consequences of idiopathic scoliosis 5 years after surgical treatment. Transpedicular fixation without correction of the deformity.

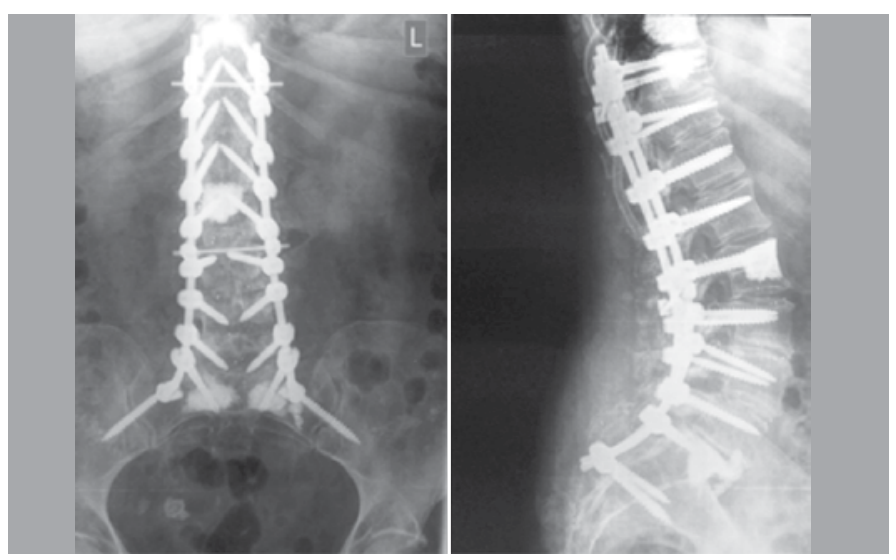

Figure 2. Transpedicular system installed up to the lower-thoracic region of the spine with cement augmentation. were correlated with the less aggressive surgery. In Groups C and $D$, there was no statistically significant difference between the preoperative and postoperative pain levels. During the early follow-up period, the pain level tended to decrease unevenly in all the groups.

In Group A, the level of pain increased. This can be explained by the increasing instability of the spinal column confirmed in the functional X-ray films. In Groups B and C, significant positive dynamics were observed, which can be attributed to the adaptation to new conditions of balance, the healing process in the area of surgical approach, and the formation of a primary bone block.

During the second follow-up period, the patients of Groups A, $B$ and $C$ demonstrated negative dynamics with increased pain. The occurrence of the first complications was observed in this period.

The level of the pain increased, to the detriment of a continued increase in instability in the functional spinal unit (Group A) and problems with adjacent levels (Groups B, C, and D). At the same time, the patients of Group $D$ had less complications and less increase of pain.

At the end of 5 years of follow-up, pain had reached practically preoperative levels in Group A, decreased considerably in Groups $\mathrm{B}$ and $\mathrm{C}$ and decreased maximally in Group D. Meanwhile, the data for Groups B and C were comparable. (Figure 4) Comparing the changes using the Oswestry Disability Index (ODI), we obtained the data given below. (Figure 5)

In Group A, the significant postoperative improvement was replaced by gradual steady return to initial levels. There were also changes in the Oswestry Disability Index (ODI) and evaluation of patient satisfaction with the treatment (SRS-24). (Figures 4 and 5) These results are related to increasing of spinal instability and increasing pain.

In Groups B, C, and D, the ODI ratings and SRS-24 demonstrated

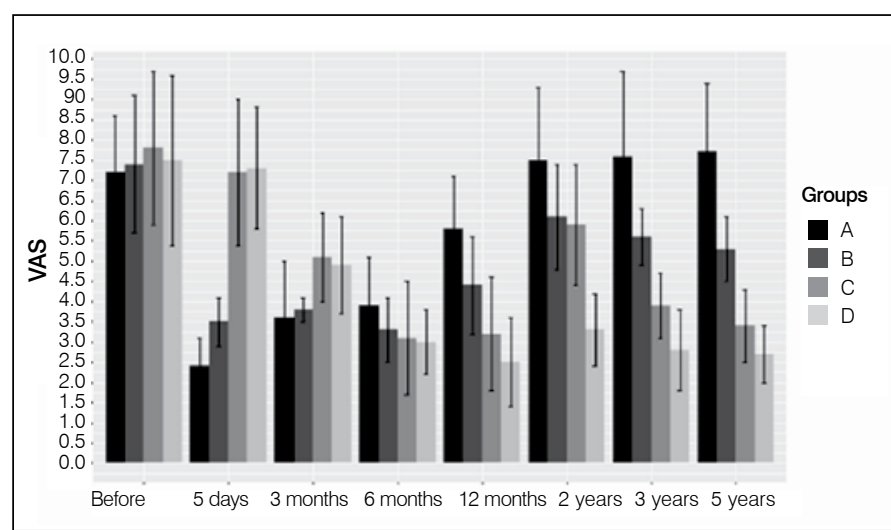

Figure 3. Pain level changing on VAS scale during 5 years, where $10=$ maximum pain, and $0=$ absence of pain. The table is based on the ratings of mean values with confidence intervals for each group.

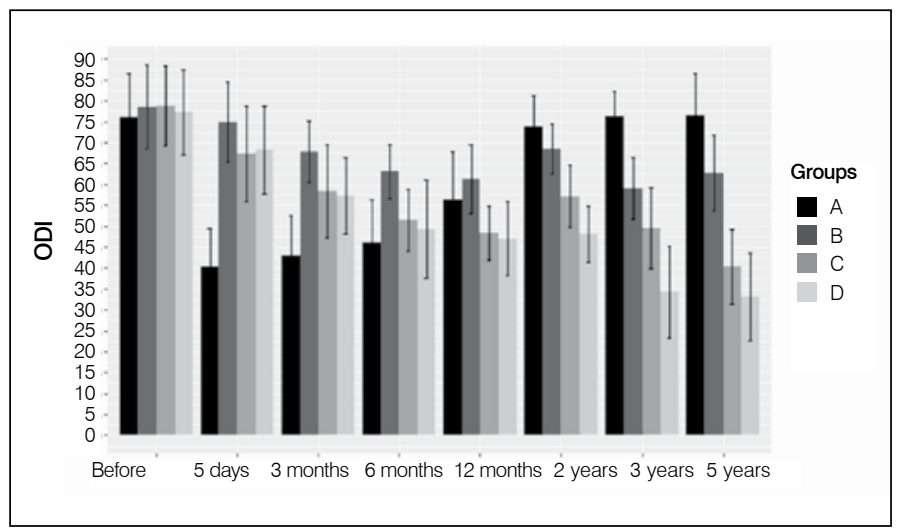

Figure 4. Changes of life quality (ODI) for 5 years for four groups, where $100=$ maximally poor quality of the life, and $0=$ maximally good quality of life. The table is based on the ratings of means with direction of confidence intervals for each group in measured periods of the time. 
a smooth tendency to improvement, related to complications, which increased during this period. (Figures 4 and 5)

In Groups A and B, no neurological infringements were observed in the postoperative period, but neurogenic lameness increased during the entire follow-up period. In Groups C and D, unilateral monoparesis of two to four degrees was observed in 18\% (Group C) and $15 \%$ (Group D), which can be explained by the nerve traction during the correction of spine deformity.

In total, at the end of five years of supervision, the lowest result was found in Group A, with 13.4\% satisfactory results (15 patients) and 86.6\% unsatisfactory results (97 patients). No good results were observed.

For the patients in Group B, good results were obtained in $19.5 \%$ (22 patients), satisfactory in 50.5\% (57 patients) and unsatisfactory in 30\% (34 patients)

For Group C, there were $24.3 \%$ good results (26 patients), $45.7 \%$ satisfactory (49 patients), and 30\% unsatisfactory (32 patients). (Figure 5)

The best outcome was obtained in Group D, with $57.2 \%$ good results (60 patients), 40\% satisfactory results (42 patients), and $2.8 \%$ unsatisfactory (3 patients). (Figure 6) These data confirm the statistical validity of the distinctions in relation to the surgical treatment results.

Comparative results of the clinical research are shown in Table 3 and Figure 7.

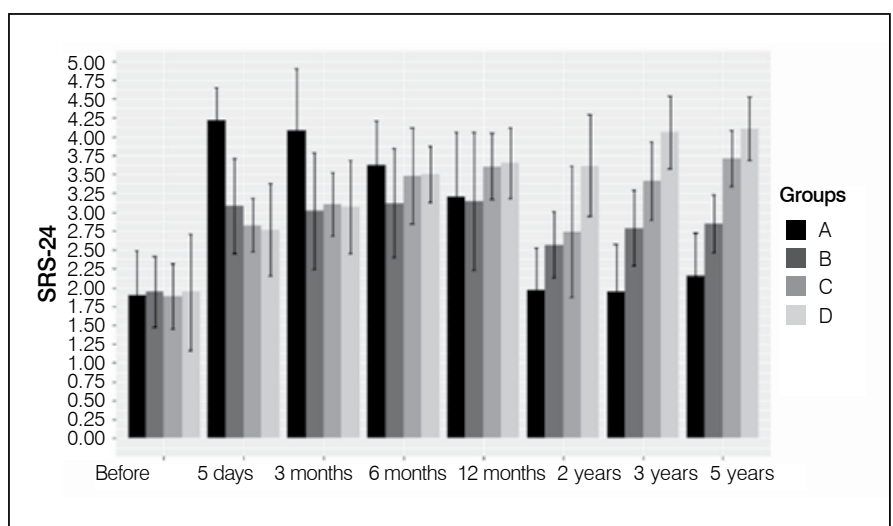

Figure 5 . Changes of quality of life and satisfaction by results of surgical treatment on SRS-24 for 5 years in four groups, where $5=$ maximally good result, and $1=$ maximally poor result. The table is based on the ratings of means with direction of confidence intervals for each group in measured periods of the time.

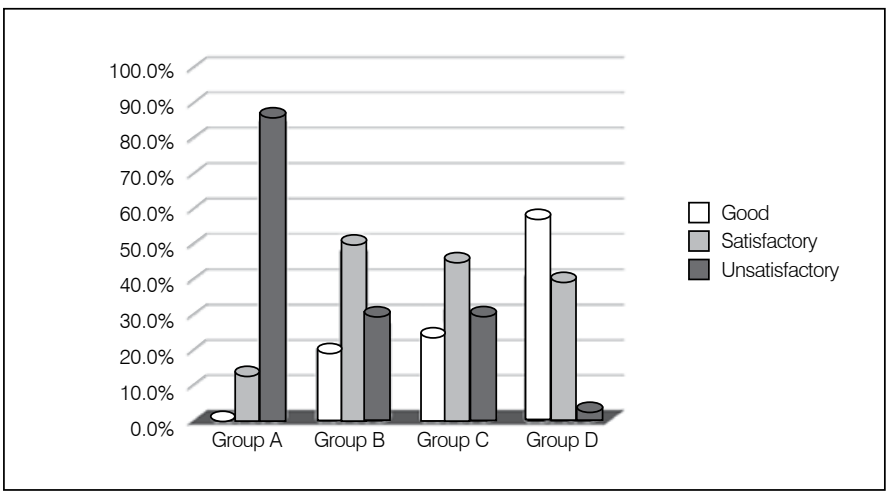

Figure 6. Results of the treatment in all groups 5 years postoperative. The value of $\chi^{2}$ is 205.801. Critical value $\chi^{2}$ is 16.812 (at value $p<0.01$ )

\section{Surgical complications}

The following complications were observed: increasing neurological deficit, with acute pain syndrome, instability and (or) construction fracture, adjacent segment disease with instability and (or) vertebral fractures of the adjacent level.

In total, revision surgeries due to complications were carried out in $29 \%$ (127 cases) at 113 patients (25.8\%). Of these, 8.7\% (38 operations, 30\% from all complications) involved reinstallation of the metal construction due to instability or breakage (24 subjects, 5.5\% of the total). However, for Group A this complication was not typical. In Group $B$, there were 8 cases (21\% of the total with this type of complication), in Group C there were 26 cases (68.4\%) and in Group D there were 4 cases (10.6\%) (Figure 7). Operations due to neurologic infringements were performed in $13.3 \%$ cases (58 operations, $45.6 \%$ of all complications). In Group A, there were 28 cases (48.3\%), in Group B, 13 cases (22.4\%), in Group C, 15 cases (25.9\%) and in Group D, 2 cases (3.4\%). Pathology of adjacent segment was revealed in $7 \%$ (31 cases, $24.4 \%$ of all complications). In Group A, no complications were observed. In Group B there were 12 cases (38.8\%), in Group C, 18 cases (58\%) and in Group D only one case (3.2\%) (Figure 8).

\section{DISCUSSION}

Vakkaro and Sharik suggest that decompression can result in greater collapse of the functional spinal unit, instability, and exacerbation of the lumbar deformity, resulting in increasing pain, to the detriment of strengthened spinal stenosis. This authors ascribe to the tactics of executing decompression and fixation with correction of the deformity. ${ }^{13}$

Our research was performed to determine the efficiency of various surgical methods in elderly persons with deformities of the spinal column. The patients were divided into four groups, depending on the extent of surgical intervention performed.

It was noted that patients of Group A withstood the operation better than others in the nearest follow-up period, but in the later follow-up period, the results for this group were unsatisfactory.

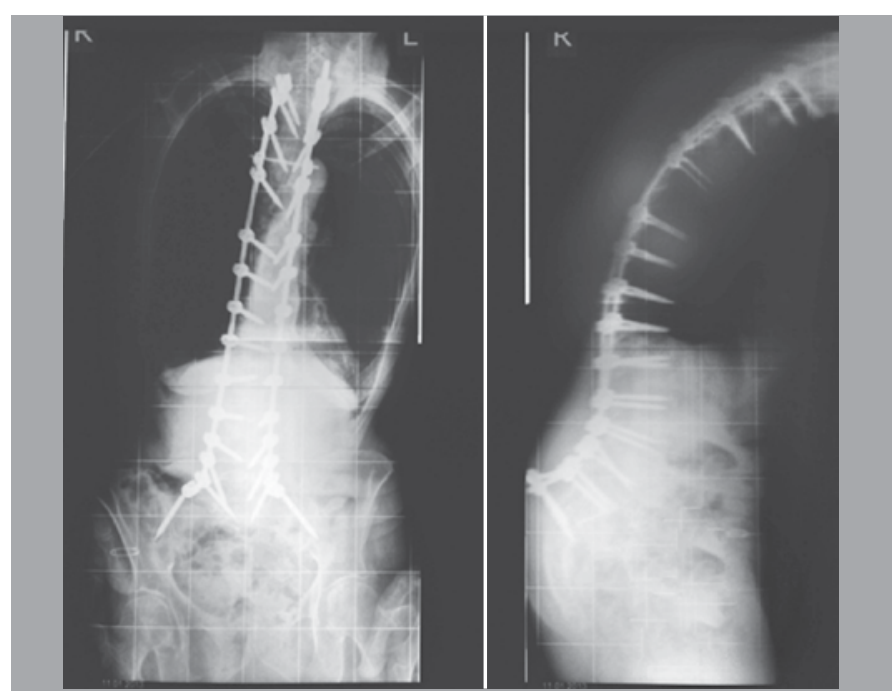

Figure 7. X-ray film of female 74 years, in first year postoperative, AP and lateral views. Loss of correction with construction instability. Positive sagittal balance $S V A+68 \mathrm{~cm}$, frontal imbalance $12 \mathrm{~cm}$, lordosis angle $\mathrm{LL}=32^{\circ}$.

Table 3. Master table of treatment results in 5 years.

\begin{tabular}{|c|c|c|c|c|c|c|c|c|}
\hline \multirow{2}{*}{ Groups } & \multicolumn{4}{|c|}{ Preoperative } & \multicolumn{4}{|c|}{5 years postoperative } \\
\hline & VAS (SD) & ODI (SD) & SRS-24 (SD) & Paresis\% SD) & VAS (SD) & ODI (SD) & SRS-24 (SD) & paresis (SD) \\
\hline$A$ & $8( \pm 2.2)$ & $77.4( \pm 4.1)$ & $1.9( \pm 0.6)$ & - & $8( \pm 2.4)$ & $76.5( \pm 2.1)$ & $2.2( \pm 0.6)$ & - \\
\hline $\mathrm{B}$ & $8( \pm 2.4)$ & $78.5( \pm 3.8)$ & $1.9( \pm 0.5)$ & - & $4( \pm 1.2)$ & $53.7( \pm 5.8)$ & $2.9( \pm 0.3)$ & - \\
\hline $\mathrm{C}$ & $8( \pm 1.9)$ & $78.1( \pm 4.2)$ & $1.9( \pm 0.4)$ & - & $4.0( \pm 0.7)$ & $45.3( \pm 4.7)$ & $3.7( \pm 0.4)$ & $6( \pm 0.7)$ \\
\hline $\mathrm{D}$ & $8( \pm 2.3)$ & $77.3( \pm 3.2)$ & $1.9( \pm 0.8)$ & - & $3.0( \pm 1.5)$ & $37.1( \pm 3.4)$ & $4.1( \pm 0.4)$ & $3( \pm 0.5)$ \\
\hline $\mathrm{P}$ value & 0.24 & 0.19 & 0.38 & - & 0.036 & 0.012 & 0.025 & 0.0027 \\
\hline
\end{tabular}




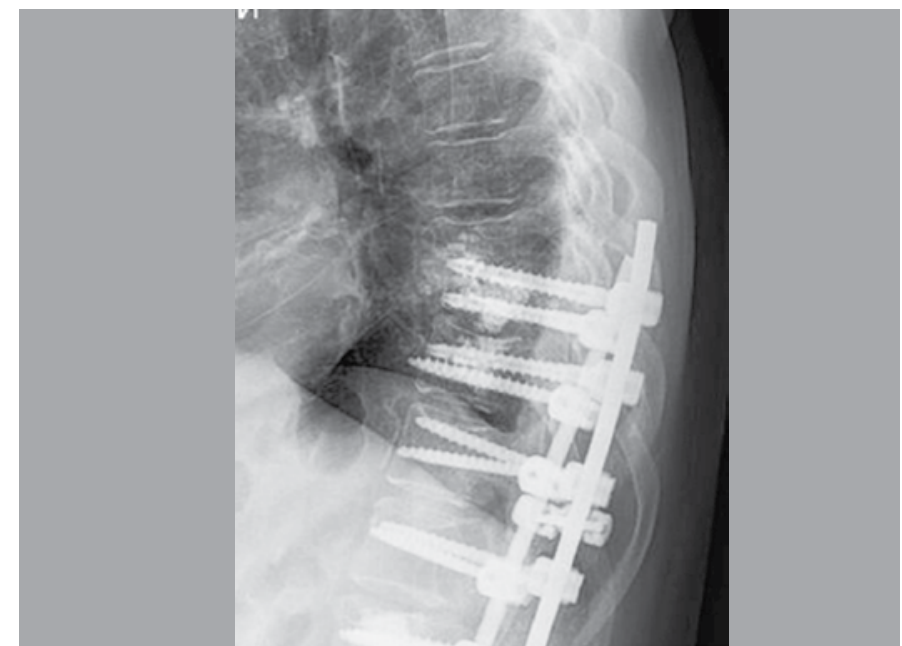

Figure 8. X-ray of a female aged 79 years, the first year postoperative. Fracture of the body Th8.

We observed the highest level of good clinical results for correction of deformity among the patients who underwent spinal osteotomies and multiply level fixation (55.5\% of all good results), which corroborates the studies of Vakkaro and Sharik. For patients who received only decompression of the spinal stenosis, satisfactory results were observed only during the first month of follow-up. Furthermore, instability increasing, pain, and neurogenic lameness was observed (in 97 patients, 58.4\%).

The results contradict the claim of Vakkaro and Sharik concerning the opportunity to use only local decompression in patients with degenerative deformities. ${ }^{8}$

At the same time, the amount of surgical and somatic complications in all groups was comparable, and we can establish that there is no direct correlation with the extent of surgery or the frequency of the above-stated complications. 2,14

This result contradicts the belief that more aggressive surgery increases the risk of complications. ${ }^{10,15,16}$

Specific complications associated with applying various implants or levels selection for fixation were revealed in Groups B and C (21\% and $68.4 \%$ respectively), where correction of the deformity was either not performed (Group B), or was performed with "short fixation", that didn't allow spinal balance be adjusted.

The same tendency was noted for problems with the adjacent segment. In Group B, there were 12 such cases (38.8\%), with 18 cases in Group C (58\%) and one case in Group D (3.2\%). This also confirms the results of Vakkaro and Sharik.

Based on our results, we recommend decompressive foraminotomy if there is restabilization of the compromised spinal unit and absence of development of the deformity. And against a background of compensated balance, is preferable to use only decompression foraminotomy. For proven instability, the method of choice should be decompression of the spinal channel, stabilization of the spine with transpedicular fixation, cement augmentation, and spinal osteotomy. At the same time, long fixation is better than short fixation due to the risk of adjacent segment disease. Our conclusions partly confirm the supporters and opponents of stabilization of spine column. $3,8,15,17$

\section{CONCLUSIONS}

Based on the data obtained, it can be seen, that the majority of complications were associated with neurological problems (included acute pain syndrome, paresis and paresthesia due to nerve traction, ischemia or injury). More complications were found in Group C than in Group D.

This analysis showed that incomplete correction of the deformity could lead to its loss, vertebral or construction fractures, and screw migration. Correction of sagittal balance (SVA $<4 \mathrm{~cm}$ ) or pelvic indices using the formula PI+TK+LL $\leq 45^{\circ}$ or only frontal balance is insufficient, as it can lead to loss of correction, and complications.

The risk of adjacent segment pathology among patients of elderly and senile age is "short" fixation (Th10 or L1) with pelvic ring.

In patients of this age, there is no compensation of the remaining deformity in the thoracic region, compared with younger adults. Therefore, for elderly patients, transpedicular fixation could be recommended, extended up to Th4. The conclusions are based on an analysis of X-ray films taken from of Groups B, C and D.

According to the findings of our study, we recommend performing full deformity correction with transpedicular fixation as far as the higher-thoracic region in elderly patients. This approach enables the best results, while avoiding complications in long-term outcomes.

All authors declare no potential conflict of interest related to this article.

CONTRIBUTION OF THE AUTHORS: AD (0000-0001-8113-2395)* and DM (0000-0002-4747-0806)* - review and approval of the final version of the work. DP $(0000-0001-5765-3158)^{\star}$, NZ (0000-0003-4562-8160)* and SM (0000-0002-9853-7089)* - active participation in the discussion of results. *ORCID (Open Researcher and Contributor ID).

\section{REFERENCES}

1. Albert TJ, Purtil J, Mesa J, McIntosh T, Balderston RA. Health outcome assessment before and after adult deformity surgery: A prospective study. Spine (Phila Pa 1976). 1995;20(18):2002-2005.

2. Fischer CR, Terran J, Lonner B, McHugh B, Warren D, Glassman S, et al. Factors predicting cost-effectiveness of adult spinal deformity surgery at 2 years. Spine Deform. 2014:2(5):415-422.

3. DeWald CJ, Stanley T. Instrumentation-related complications of multilevel fusions for adult spinal deformity patients over age 65: Surgical considerations and treatment options in patients with poor bone quality. Spine (Phila Pa 1976). 2006:31(19 SUPPL.)S144-51.

4. Silva FE, Lenke LG. Adult degenerative scoliosis: evaluation and management. Neurosurg Focus. 2010;28(3):E1.

5. Transfeldt EE, Topp R, Mehbod AA, Winter RB. Surgical outcomes of decompression, decompression with limited fusion, and decompression with full curve fusion for degenerative scoliosis with radiculopathy. Spine (Phila Pa 1976). 2010:35(20):1872-5.

6. Seo HJ, Kim HJ, Ro YJ, Yang HS. Non-neurologic complications following surgery for scoliosis. Korean J Anesthesiol. 2013;64(1):40-46

7. Smith JS, Kasliwal MK, Crawford A, Shaffrey Cl. Outcomes, Expectations, and Complications Overview for the Surgical Treatment of Adult and Pediatric Spinal Deformity. Spine Deform. 2012

8. Glassman SD, Dimar JR, Carreon LY. Revision rate after adult deformity surgery. Spine Deform. 2015;3(2):199-203.

9. Ploumis A, Transfledt EE, Denis F. Degenerative lumbar scoliosis associated with spinal stenosis. Spine J. 2007;7(4):428-36.
10. Weber $\mathrm{MH}$, Mathew JE, Takemoto $\mathrm{SK}, \mathrm{Na} \mathrm{LH}$, Berven $\mathrm{S}$, Spinal Seformity Study Group. Postoperative recovery outcomes in adult scoliosis: A prospective multicenter database with 5-year follow-up. Spine Deform. 2014;2(3):226-32.

11. Yadla S, Maltenfort MG, Ratliff JK, Harrop JS. Adult scoliosis surgery outcomes: a systematic review. Neurosurg Focus. 2010;28(3):E3.

12. Schwab F, Ungar B, Blondel B, Buchowski J, Coe J. Scoliosis Research SocietySchwab Adult Spinal Deformity Classification: a validation study. Spine (Phila Pa 1976). 2012;37(12):1077-82

13. Dangelmajer S, Zadnik PL, Rodriguez ST, Gokaslan ZL, Sciubba DM. Minimally invasive spine surgery for adult degenerative lumbar scoliosis. Neurosurg Focus. 2014;36(5):E7.

14. Cho KJ, Suk SI, Park SR, Kim JH, Kim SS, Choi WK, et al. Complications in posterior fusion and instrumentation for degenerative lumbar scoliosis. Spine (Phila Pa 1976). 2007:32(20):2232-7.

15. Carreon LY, Puno RM, Dimar JR 2nd, Glassman SD, Johnson JR. Perioperative Complications of Posterior Lumbar Decompression and Arthrodesis in Older Adults. J Bone Joint Surg Am. 2003;85(11):2089-92.

16. Raffo CS, Lauerman WC. Predicting morbidity and mortality of lumbar spine arthrodesis in patients in their ninth decade. Spine (Phila Pa 1976). 2006:31(1):99-103.

17. Park JJ, Carreon LY, Glassman SD. Adult lumbar degenerative scoliosis $40^{\circ}$ or less: Outcomes of surgical treatment with minimum 2-year follow-up. Spine Deform. 2013;1(3):211-216 